\title{
Determination of myocardial and serum digoxin concentrations in children by specific and nonspecific assay methods
}

\begin{abstract}
After obtaining samples at open heart surgery, serum and right atrial digoxin concentrations were measured in 25 children by a nonspecific, direct radioimmunoassay method (NS) and by a specific method in which digoxin was separated from its metabolites by HPLC before radioimmunoassay was applied to the digoxin fraction (S). Digoxin was detectable by $S$ assay (sensitivity $0.1 \mathrm{ng} / \mathrm{g}$ ) in 16 heart specimens and 22 serum samples. The mean and range of the S/NS ratio was $0.74(0.23$ to 2.63) for serum and 0.81 (0.068 to 1.38) for atrial tissue. By NS assay the mean and range of the atrial/serum ratio was $78.1(2.4$ to $340, n=21)$ and by $S$ assay the corresponding values were $100(10.7$ to $318, n=15)$. A multiple linear regression indicated that $72.5 \%$ of the variance of the heart digoxin concentrations measured by $S$ assay were accounted for by the variables height, body weight, daily digoxin dose before operation, plasma digoxin concentration by $S$ assay, and BUN.
\end{abstract}

John G. Wagner, Ph.D., D.Sc., Macdonald Dick II, M.D., Douglas M. Behrendt, M.D., Graham F. Lockwood, Ph.D., Ermelinda Sakmar, M.A., and Paul Hees, B.S.

Ann Arbor, Mich.

College of Pharmacy, The Upjohn Center for Clinical Pharmacology, and Departments of

Pediatrics and Surgery, The University of Michigan

The therapeutic activity of digoxin has been related, at least in part, to the concentration of the drug in myocardium, which, in turn, should be related to the serum level. ${ }^{22}$ Although the earliest studies ${ }^{4,10,11,20}$ in which myocardial digoxin concentrations were measured involved the administration of ${ }^{3} \mathrm{H}$-digoxin to the patients and were nonsteady-state studies, all subsequent studies ${ }^{8,9,18,19,22,23,26,32}$ have been steady-

Supported by National Institutes of Health grant No. HL 23862. Received for publication Oct. 21, 1982.

Accepted for publication Dec. 13, 1982.

Reprint requests to: Dr. John G. Wagner, Upjohn Center for Clinical Pharmacology, The University of Michigan Medical Center, Ann Arbor, MI 48109. state studies and have involved the use of radioimmunoassay (RIA) to measure digoxin concentrations in both heart tissue and serum or plasma. With the use of these techniques, digoxin concentrations have been shown to differ among various sites within the human heart, ${ }^{3,9,23}$ but not during cardiopulmonary bypass. ${ }^{4,20,26}$

Myocardial digoxin/plasma or serum digoxin mean ratios appear to be considerably higher in infants ( $\leq 1 \mathrm{yr}$ of age) than in adults, but only two studies appear to have been carried out in children (excluding infants). The study of Hernandez et al.$^{20}$ was a nonsteady-state study and involved digitalization of nine children with ${ }^{3} \mathrm{H}$-digoxin just 2 days before open heart surgery. The study of Krasula et al. ${ }^{26}$ in 42 chil- 
dren involved 18 children who had been receiving maintenance digoxin for a month or longer and the authors reported a mean right atrial appendage (RAA) digoxin concentration of 62 $\mathrm{ng} / \mathrm{gm}$ and a mean serum digoxin concentration of $1.2 \mathrm{ng} / \mathrm{ml}$ in the latter. However, they reported no individual patient data.

One of the authors ${ }^{35}$ of the present report has shown that the digoxin metabolites digoxigenin-mono-digitoxoside, digoxigenin-bis-digitoxoside, and digoxigenin cross react extensively in RIA. Kramer et al ${ }^{25}$ showed that dihydrodigoxin also cross reacts. Recently digoxin has been separated from its metabolites by HPLC in small enough samples to make the technique applicable to the therapeutic situation. If the digoxin fraction at the end of the HPLC column is collected, and by either applying the RIA or measuring radioactivity when radiolabeled digoxin was used, specific assay methods for digoxin have been made available..$^{13,28-31}$ Also, a more complicated assay, involving different methods and the use of radiolabeled digoxin, has been described. ${ }^{12}$

With presently available assay methods, studies have been carried out to determine to what degree digoxin concentrations measured by the specific (S) and the conventional nonspecific (NS) RIA differ. Gibson and Nelson ${ }^{16,17}$ reported that plasma digoxin concentrations measured by specific HPLC assay and direct ${ }^{125}$ I-RIA are essentially identical when glomerular filtration rate is $40 \mathrm{ml} / \mathrm{min}$ or more; in contrast the ratio of $\mathrm{S} / \mathrm{NS}$ values was $0.83 \pm 0.12$ (mean $\pm \mathrm{SD}$ ) in renal failure patients. Wagner et al. ${ }^{37}$ reported no significant differences between results with a specific assay ${ }^{30}$ and the ${ }^{3} \mathrm{H}$-digoxin $\mathrm{RIA}^{36}$ with groups of 17 randomly selected plasma samples and 34 randomly selected urine samples from a study in normal adult male subjects. Loo et al. ${ }^{29}$ reported a mean ratio of $\mathrm{S} / \mathrm{NS}$ digoxin in serum of $0.84 \pm 0.12$ in 14 digitalized patients of unknown renal status. Gault et al..$^{15}$ reported considerably larger percentages of a single dose of ${ }^{3} \mathrm{H}$-digoxin excreted in the urine in 5 days as unchanged digoxin and metabolites in six patients with normal renal function compared with six patients with minimal renal function.

Our purposes were to measure myocardial and serum digoxin concentrations in children, on whom available information is minimal, and to compare results of the nonspecific direct RIA with results obtained with a new specific HPLCRIA method.

\section{Methods}

The study population consisted of 25 children from 9 mo to $18 \mathrm{yr}$ old who were undergoing intracardiac repair of various congenital heart defects. Each child had been taking digoxin over a long term $(21 \mathrm{mo})$ for up to $24 \mathrm{hr}$ before open heart surgery. A 5- to $10-\mathrm{ml}$ blood sample was obtained during operation before cardiopulmonary bypass; part of the blood was used for serum creatinine determination and the remainder was converted to serum and quickfrozen for digoxin assays at a later date. A heart tissue sample from the right atrial appendage, routinely removed for cannulation and discarded, was obtained just before the institution of cardiopulmonary bypass. Fat tissue was removed; the tissue was then frozen and stored at $-20^{\circ}$.

The frozen tissue samples were thawed at one time and their wet weights measured (range 40 to $250 \mathrm{mg}$ ); the samples were then lyophilized in $15-\mathrm{ml}$ screw-top test tubes. The lyophilized cake was finely ground with a glass rod and any dried tissue remaining on the rod was washed into the bottom of the tube with a small volume of methylene chloride. Internal standard solution (100 $\mu \mathrm{l}$ of a $20 \mu \mathrm{g}$ solution of ethoxzolamide in water) was added along with $4 \mathrm{ml}$ of methylene chloride. The tubes were capped, vigorously shaken for $10 \mathrm{~min}$, gently centrifuged, then the methylene chloride extract was transferred to a clean test tube. The extraction procedure was repeated three times to give a final methylene chloride extract volume of about $12 \mathrm{ml}$. This extract was divided into two portions and each was evaporated to dryness to provide dry residues for the $\mathrm{S}$ and NS assays. For the $\mathrm{S}$ assay the residue was reconstituted in $150 \mu \mathrm{l}$ of methanol and $3 \mu \mathrm{l}$ of a $2-\mathrm{mg} / \mathrm{ml}$ solution of nalorphine was added as a marker. This marker was chosen since the end of its peak, measured in the UV $(254 \mathrm{~nm})$, coincided with the beginning of elution of the digoxin fraction. Of this mixture $100 \mu \mathrm{l}$ was injected onto the 
HPLC column. Standard curves were prepared by spiking lyophilized dog heart samples ( 250 mg wet weight) with digoxin over a range of 4 to $200 \mathrm{ng} / \mathrm{gm}$ wet tissue and processing as described above. Digoxin concentrations in the human RAA samples were calculated with reference to these standard curves and the concentrations are expressed as nanograms of digoxin per gram wet atrium. It is feasible that by the use of methylene chloride to extract digoxin from heart tissue one or more metabolites of digoxin were excluded from the organic extract and left in the aqueous phase, thus making the NS heart assay inherently more specific than the NS serum assay, in which extraction was not involved.

For the specific assay of serum $1 \mathrm{ml}$ of serum, $100 \mu \mathrm{l}$ of a $20 \mu \mathrm{g} / \mathrm{ml}$ solution of ethoxzolamide as internal standard, $50 \mu \mathrm{l}$ of $1.5 \mathrm{M}$ $\mathrm{HCl}$, and $12 \mathrm{ml}$ of methylene chloride were placed in a $15-\mathrm{ml}$ test tube with a Teflon-lined screw cap in place. The tube was shaken for 10 min then centrifuged for $5 \mathrm{~min}$ at $2500 \mathrm{rpm}$. The supernatant aqueous layer was discarded and the organic layer was transferred to a $10-\mathrm{ml}$ test tube; the extract was then evaporated to dryness with a stream of nitrogen. Just before chromatography the dried residue was reconstituted in $150 \mu \mathrm{l}$ of methanol and $3 \mu \mathrm{l}$ of a $2-\mathrm{mg} / \mathrm{ml}$ solution of nalorphine was added as marker. Of this, $100 \mu \mathrm{l}$ was injected onto the HPLC column.

The $S$ assay for both serum and atrial tissue was an adaptation of the method of Morais et al $^{30}$ in which a different internal standard, marker, and chromatography method were used. The chromatography system consisted of an LDC minipump (Milton Roy), a C-18 $\mu$ Bondapak column (Waters Associates), and a model HM Holochrome variable-wavelength detector (Gilson Medical Electronics). Samples were loaded onto the column with a Rheodyne 7010 loop injector (Rheodyne Ltd.). The eluting solvent was $30 \%$ acetonitrile, $70 \% \quad 0.025 \mathrm{M}$ $\mathrm{KH}_{2} \mathrm{PO}_{4}$, buffered to $\mathrm{pH} 6.9$ with $1 \mathrm{~N} \mathrm{KOH}$. The flow rate was $3 \mathrm{ml} \mathrm{min}{ }^{-1}$. The detector wavelength was $254 \mathrm{~nm}$ at 0.02 AUFS. The eluent fraction between the end of the nalorphine peak and the beginning of the ethoxzolamide peak was collected and this fraction had been shown to be the one containing the digoxin. The fraction col- lected was evaporated to dryness at $37^{\circ}$ under a stream of air. To the residue from the latter (obtained from either plasma or heart tissue) was added $1 \mathrm{ml}$ of digoxin-free plasma and the RIA as described by Wagner et al ${ }^{36}$ was carried out .

The NS assay for plasma was carried out with $1 \mathrm{ml}$ of the patient plasma rather than the digoxin-free plasma and residue as described above. The NS assay for the RAA samples was carried out by adding $1 \mathrm{ml}$ of digoxin-free plasma to the residue from the methylene chloride extract above. In both cases the RIA as described by Wagner et al ${ }^{36}$ was then carried out.

Statistics. The correlation coefficient ( $r$ ) and standard deviation of scatter about regression value (s) were calculated with equations 1 and 2 as follows:

$$
\begin{gathered}
r=\sqrt{1-\frac{\sum(\mathrm{Y}-\hat{\mathrm{Y}})^{2}}{\sum(\mathrm{Y}-\overline{\mathrm{Y}})^{2}}} \\
\mathrm{~s}=\sqrt{\frac{\sum(\mathrm{Y}-\hat{\mathrm{Y}})^{2}}{\mathrm{~N}-\mathrm{P}}}
\end{gathered}
$$

where $\mathrm{Y}$ is the observed value of the dependent variable, $\hat{Y}$ is the estimated value of the dependent variable, $\bar{Y}$ is the average value of the dependent variable, $\mathrm{N}$ is the number of data points, and $\mathrm{P}$ is the number of parameters estimated.

\section{Results}

Table I lists demographic data along with serum and RAA digoxin concentrations measured by NS and $S$ assay methods. Digoxin was detectable in 22 of 25 RAA samples by NS assay, but only in 16 of 25 by $S$ assay. Digoxin was detectable in 24 out of 25 serum samples by NS assay, but in only 22 out of 25 by S assay (with a sensitivity limit of $0.1 \mathrm{ng} / \mathrm{ml}$ ). Averages and ranges were: serum digoxin by NS assay, $0.809(0.062$ to 1.89$) \mathrm{ng} / \mathrm{ml}$; serum digoxin by $\mathrm{S}$ assay, $0.520(<0.1$ to 1.26$) \mathrm{ng} / \mathrm{ml}$; RAA digoxin by NS assay, 48.1 (1.2 to 178$) \mathrm{ng} / \mathrm{gm}$ wet; RAA digoxin by $S$ assay, 48.7 (2.6 to 159 ) $\mathrm{ng} / \mathrm{gm}$ wet; RAA/serum ratio, 78.1 (2.4 to 340 ) by NS assay and 84.7 (omitting patient N. R.) (10.7 to 190) by $S$ assay; S/NS ratio, $0.74(0.23$ to 2.63$)$ for serum and $0.81(0.062$ to 1.38$)$ for RAA.

Various correlations were examined in which RAA digoxin concentrations by $\mathrm{S}$ assay were 
Table I. Demographic data and digoxin concentrations in serum and RAA tissue by $S$ and NS assay

\begin{tabular}{|c|c|c|c|c|c|c|c|c|}
\hline Patient & Sex & $\begin{array}{l}\text { Age } \\
(y r)\end{array}$ & $\begin{array}{c}\text { Body } \\
\text { weight } \\
(\mathrm{kg})\end{array}$ & $\begin{array}{l}\text { Height } \\
(\mathrm{cm})\end{array}$ & $\begin{array}{l}\text { Surface } \\
\text { area } \\
\left(m^{2}\right)\end{array}$ & $\begin{array}{l}\text { Serum } \\
\text { creat. } \\
(\mathrm{mg} / \mathrm{dl})\end{array}$ & $\begin{array}{c}B U N \\
(\mathrm{mg} / \mathrm{dl})\end{array}$ & $\begin{array}{c}\text { Dig. } \\
\text { dose } \\
\text { ( } \mu \text { g b.i.d.) }\end{array}$ \\
\hline A. B.* & $M$ & 3.5 & 11.2 & 76 & 0.46 & 0.3 & 16 & 30 \\
\hline J. C. ${ }^{*}$ & M & 2.5 & 5.7 & 65.5 & 0.3 & 0.5 & 11 & 28 \\
\hline C. F.* & $\mathrm{F}$ & 2. & 5.5 & 67 & 0.3 & 0.4 & 11 & 25 \\
\hline D. G.* & M & 3 & 7.42 & 76 & 0.39 & 0.3 & 11 & 45 \\
\hline E. H.* & F & 2 & 4.40 & 64 & 0.27 & 0.3 & 8 & 20 \\
\hline C. $\mathrm{H}^{*}$ & M & 3 & 6.64 & 68 & 0.34 & 0.3 & 14 & 35 \\
\hline D. H.* & M & 2 & 7.1 & 70 & 0.36 & 0.2 & 9 & 30 \\
\hline J. S.* & M & 3.5 & 8.26 & 81 & 0.22 & 0.5 & 20 & 25 \\
\hline C. T.* & M & 2 & 4.0 & 57 & 0.24 & 0.3 & 7 & 18 \\
\hline R. $\mathrm{H}$. & M & 5 & 12.8 & 93 & 0.57 & 0.4 & 15 & 45 \\
\hline A. B. & F & 4 & 13.1 & 96 & 0.59 & 0.4 & 13 & 50 \\
\hline N. B. & F & 3 & 7.56 & 71.5 & 0.37 & 0.4 & 10 & 30 \\
\hline W. C. & $\mathrm{F}$ & 5.5 & 8.22 & 77 & 0.4 & 0.4 & 21 & 35 \\
\hline F. F.* & $\mathrm{F}$ & 3 & 9.5 & 82 & 0.45 & 0.3 & 15 & 50 \\
\hline T. K.* & $\mathrm{F}$ & 2.5 & 7.38 & 73 & 0.38 & 0.5 & 18 & 35 \\
\hline B. L. & M & 18 & 88.0 & 173 & 2.02 & 1.0 & 12 & 125 \\
\hline B. R. & M & 2 & 7.6 & 73 & 0.38 & 0.2 & 10 & 30 \\
\hline $\mathrm{K} \cdot \mathbf{R} *{ }^{*}$ & $\mathrm{M}$ & 1 & 7.4 & 71.5 & 0.37 & 0.5 & 33 & 25 \\
\hline T. C. & F & 4 & 9.8 & 91 & 0.50 & 0.5 & 14 & 50 \\
\hline A. W.* & F & 13 & 31.0 & 140 & 1.11 & 0.8 & 17 & 100 \\
\hline D. A. & M & 1 & 4.26 & 57 & 0.18 & 0.4 & 14 & 22.5 \\
\hline A. S. & $\mathrm{F}$ & 15 & 96.0 & 165 & 2.02 & 1.1 & 18 & 250 \\
\hline S. J.* & $\mathrm{M}$ & 1.5 & 5.7 & 68 & 0.32 & 0.4 & 10 & 25 \\
\hline N. R.* & M & 0.75 & 3.7 & 55 & 0.23 & 0.4 & 8 & 17 \\
\hline A. $\mathrm{H}$ & M & 10 & 18.1 & 108 & 0.73 & 0.8 & 5 & 70 \\
\hline & & & & & & & \multirow{2}{*}{\multicolumn{2}{|c|}{$\begin{array}{l}\text { Average } \\
\text { Average w/o N.R. } \\
\text { CV }(\%)\end{array}$}} \\
\hline & & & & & & & & \\
\hline
\end{tabular}

$\mathrm{ND}=$ not detectable.

*These 15 patients were grouped together for the correlations described in Results, as were the remaining 14 patients

correlated with either individual variables, including age, height, body weight, lean body mass, dose of digoxin, BUN, serum creatinine concentration, body surface area, and serum digoxin, or with various combinations of multiple variables. For these correlations $n=15$ (indicated in Table I) or $\mathrm{n}=14$ (omitting patient N. R.). Most single independent variable correlations gave correlation coefficients in the range 0.2 to 0.4 . The exception was when $Y=R A A$ digoxin and $X=$ plasma digoxin, both by $S$ assay, and $n=14$, which gave:

$\hat{\mathrm{Y}}=18+40 \mathrm{X}(\mathrm{r}=0.697$

$0.001>\mathrm{P}>0.01 ; \mathrm{s}=16.1 \mathrm{ng} / \mathrm{gm})$
For the same 14 patients the NS assay results gave the nonsignificant $r$ value of 0.526 with an intercept of 34 and a slope of 24 .

The best multiple correlation found with the $\mathrm{S}$ assay results was as follows:

$$
\begin{array}{r}
\hat{\mathrm{Y}}=183+0.552 \mathrm{X}_{1}-3.42 \mathrm{X}_{2}+ \\
7.54 \mathrm{X}_{3}+0.322 \mathrm{X}_{4}+36.8 \mathrm{X}_{5} \\
(\mathrm{n}=14 ; \mathrm{r}=0.852 ; 0.02>\mathrm{P}>0.01 ; \mathrm{s}=14.4 \mathrm{ng} / \mathrm{gm})
\end{array}
$$

where $\hat{Y}$ is the estimated RAA digoxin concentration (ng/gm wet), $X_{1}$ is BUN (mg/dl), $X_{2}$ is height $(\mathrm{cm}), X_{3}$ is body weight $(\mathrm{kg}), X_{4}$ is digoxin dose $(\mu \mathrm{g} /$ day $)$, and $X_{5}$ is plasma digoxin concentration by $\mathrm{S}$ assay $(\mathrm{ng} / \mathrm{ml})$. Use of lean 


\begin{tabular}{ll|c|c|c|c}
\hline \multicolumn{2}{c|}{$\begin{array}{c}\text { Serum } \\
\text { digoxin } \\
\text { (ng/ml) }\end{array}$} & \multicolumn{2}{c|}{$\begin{array}{c}\text { RAA } \\
\text { digoxin } \\
\text { (ng/g) }\end{array}$} & \multicolumn{2}{c}{$\begin{array}{c}\text { Ratio: } \\
\text { RAA/serum }\end{array}$} \\
\hline NS & $S$ & $N S$ & $S$ & $N S$ & $S$ \\
\hline 0.530 & 0.297 & 83.4 & 56.5 & 157.0 & 190.0 \\
0.960 & 0.716 & 51.9 & 56.7 & 53.8 & 79.2 \\
1.14 & 1.14 & 61.0 & 73.0 & 53.5 & 64.0 \\
0.604 & 0.454 & 44.7 & 42.1 & 74.0 & 92.7 \\
1.13 & 0.738 & 44.8 & 43.5 & 39.6 & 58.9 \\
0.975 & 0.848 & 74.8 & 59.0 & 76.7 & 69.6 \\
0.90 & 1.05 & 40.3 & 28.4 & 44.8 & 27.0 \\
0.644 & 0.242 & 38.3 & 2.6 & 59.5 & 10.7 \\
0.424 & 0.269 & 40.6 & 40.9 & 95.8 & 152.0 \\
0.365 & $<0.1$ & 5.5 & ND & 15.1 & - \\
0.580 & 0.412 & 45.9 & ND & 79.1 & - \\
0.493 & 0.484 & 1.18 & ND & 2.4 & - \\
1.89 & - & 5.7 & ND & 3.0 & - \\
0.371 & 0.320 & 39.6 & 17.5 & 107.0 & 54.7 \\
1.62 & 1.26 & 81.7 & 77.0 & 50.4 & 61.1 \\
0.062 & 0.163 & 21.1 & ND & 340.0 & - \\
0.482 & 0.176 & 13.5 & ND & 28.0 & - \\
0.943 & 0.213 & 63.9 & 30.7 & 67.8 & 144.0 \\
0.300 & 0.16 & ND & ND & - & - \\
0.429 & 0.242 & 36.9 & 20.7 & 86.0 & 85.5 \\
1.45 & 1.04 & ND & ND & - & - \\
0.935 & 0.434 & ND & ND & - & - \\
1.03 & 0.288 & 55.3 & 27.7 & 53.7 & 96.2 \\
1.17 & 0.501 & 177.6 & 159.1 & 152.0 & 318.0 \\
ND & $<0.1$ & 31.6 & 43.5 & - & - \\
0.809 & 0.520 & 48.1 & 48.7 & 78.1 & 100.0 \\
& & & & 74.4 & 84.7 \\
55.4 & 66.8 & 77.0 & 73.2 & 92.8 & 76.5 \\
\hline & & & & & \\
\hline
\end{tabular}

body mass ${ }^{21}$ instead of total body weight decreased the correlation coefficient slightly to 0.834 , although previous data ${ }^{1,14,21}$ had suggested that lean body mass was preferable to total body weight in estimating dose of digoxin. NS results for the same 14 patients and variables gave $r=0.810$, but when all 21 available data sets were used the $r$ value dropped to 0.587 . Use of body weight and height as variables gave higher correlation coefficients than when body surface area, which was estimated by nomograph from weight and height, was used. The ratio of S/NS for RAA (Y) correlated with BUN (X) as follows:

$$
\begin{array}{r}
\hat{Y}=1.185-0.0296 X(\mathrm{n}=16 ; \\
\mathrm{r}=0.608 ; 0.02>\mathrm{P}>0.01)
\end{array}
$$

but not with serum creatinine concentration. The same ratio for serum, however, correlated poorly with BUN $(n=22 ; r=0.104 ; P>0.10)$.

Correlation of NS assay results (Y) with $\mathrm{S}$ results $(\mathrm{X})$ gave:

For RAA: $\hat{\mathrm{Y}}=16.7+0.898 \mathrm{X}$

$$
(\mathrm{n}=16 ; \mathrm{r}=0.904 ; \mathrm{P}<0.001)
$$

For serum: $\hat{\mathrm{Y}}=0.32+0.885 \mathrm{X}$

$$
(\mathrm{n}=22 ; \mathrm{r}=0.782 ; \mathrm{P}<0.001)
$$

It should be noted that the means of 48.1 and $48.7 \mathrm{ng} / \mathrm{gm}$ for NS and S assays of RAA tissue (Table I) are somewhat misleading since the NS mean is based on 22 patients while the $S$ mean is based on only 16 patients. For the 16 patients in whom NS and $S$ tissue values were available, for each patient the mean ratio of S/NS is 0.81 and for 12 out of the 16 the ratio is less than unity. For the same 21 patients in whom both NS and $S$ values are available for serum (but excluding patient B. L. because of spuriously low NS digoxin concentration) the mean S/NS ratio is 0.651 and for 19 out of 21 the ratio is less than unity. These results, together with the two correlations shown as equations 6 and 7 above, imply that appreciable amounts of metabolites were measured by NS assay, and that the proportion of metabolites measured in heart tissue by NS assay was less than that measured in plasma.

\section{Discussion}

Two important observations emerged from this study. First, the mean RAA/serum digoxin ratio of 78 observed among our children fell in the intermediate zone between the mean ratio $\left(23.9^{19}\right.$ to $\left.28^{32}\right)$ reported for adults on the one hand and that reported for infants $\left(149^{32}\right)$ on the other. Among our 25 children, three (K. R., D. A., N. R.) were infants ( $\leq 1 \mathrm{yr}$ old). The youngest of these (N. R., $0.75 \mathrm{yr}$ ) exhibited the highest RAA digoxin concentration and the highest RAA/serum ratio by both NS and $S$ assays.

Although the absolute amount of digoxin may differ, as noted ${ }^{3,9,23}$ among different sites within the heart in man, but perhaps not in other species, ${ }^{5}$ the ratio between tissue and serum 
digoxin appears to be reasonably constant. Gorodischer et al. ${ }^{18}$ reported a mean left ventricular/serum digoxin ratio of 146 among eight infants, of the order of the ratio found by Park who used the right atrial appendage.$^{32}$ Other investigators have shown a left ventricular/serum digoxin ratio of $35^{22}$ to $57^{18}$ and 22 to $77^{38}$ in adults, also of the order of Park's adult data. In contrast to the above experience demonstrating age-related but not anatomic site differences in serum/tissue digoxin ratios, Lang et al. ${ }^{27}$ and Kim et al ${ }^{24}$ did not find age-related differences in ventricular myocardial/plasma concentration ratios measured in postmortem human material (an observation that was supported experimentally in fetal lambs and ewes by Berman et al. ${ }^{5}$ ). Reasons for this discrepancy within the studies involving human subjects are not clear, but are probably do to the different myocardial sites, the use of postmortem material, and the differences in dose per kilogram body weight.

To examine factors that might predict the RAA concentration in our subjects, several multiple regression analyses were performed. It was found that $72.5 \%$ of the variance of the RAA digoxin concentration by specific assay could be accounted for by BUN concentration, height, body weight, digoxin dose, and digoxin serum concentration (equation 4). Similar correlations derived from data from the literature are not feasible since almost no authors report the individual patient values of such variables. An exception was the data of Jusko and Weintraub, ${ }^{22}$ who reported similar variables except for absence of the individual patient doses of digoxin. A multiple correlation with their data on 15 adults gave the equation:

$$
\begin{gathered}
\hat{\mathrm{Y}}=-1.93-0.269 \mathrm{X}_{1}+0.747 \mathrm{X}_{2}+26.9 \mathrm{X}_{3} \\
(\mathrm{n}=15 ; \mathrm{r}=0.815 ; \mathrm{P}<0.001 ; \mathrm{s}=39.9 \mathrm{ng} / \mathrm{gm})
\end{gathered}
$$

where $\hat{Y}$ is the estimated left ventricular digoxin concentration by NS assay, $X_{1}$ is the body weight $(\mathrm{kg}), X_{2}$ is serum creatinine concentration $\left(\mathrm{ml} / \mathrm{min} / 1.73 \mathrm{~m}^{2}\right)$, and $\mathrm{X}_{3}$ is the serum digoxin concentration by NS assay $(\mathrm{ng} / \mathrm{ml}$ ). Thus, because age per se as a continuous independent variable is not a good predictor of RAA concentration, whereas other factors such as weight, height, and renal function along with dose schedules are important determinants of the myocardial concentration in both children (equation 4) and adults (equation 8), our analysis, as well as recent experimental work in sheep ${ }^{6}$ does not support the widespread view that young myocardium cumulates (binds) digoxin more avidly than does adult myocardium at the same serum concentration..$^{32}$

The second important observation emerging from our study was the $\mathrm{S} / \mathrm{NS}$ digoxin RAA ratio of 0.81 . This ratio indirectly expresses the relationship between digoxin and its metabolites. A direct relationship between this ratio and age would suggest increased metabolic turnover of digoxin in the young and help explain the need and use for larger doses in infants and children. Analysis of our data yielded no such relationship. This finding, coupled to the observation ${ }^{7}$ of a similar ratio in both lambs $(0.8)$ and ewes (0.77) given digoxin supports the view that age-related differences in the effects (and uses) of digoxin are not due to variation in drug metabolism.

In summary, our data suggest that variation in RAA digoxin concentrations and digoxin serum/tissue ratios in children result, in large part, from variation in patient size and the digoxin dose used, and not from age-related differences in myocardial digoxin binding or metabolism. These observations support the recommendations ${ }^{33,34}$ regarding reduction in the amount of digoxin used in pediatric patients, particularly in small infants.

\section{References}

1. Abernathy DR, Greenblatt DJ, Smith TW: Digoxin disposition in obesity: Clinical pharmacokinetic investigation. Am Heart J 102: 740-744, 1981.

2. Arnim Th V, Krawietz W, Vogt W, Erdmann E: Is the determination of serum digoxin concentration useful for the diagnosis of digitalis toxicity? Int J Clin Pharmacol Ther Toxicol 18:261$268,1980$.

3. Anderson ICE, Bertler A, Wettrell G: Postmortem distribution and tissue concentration of digoxin in infants and adults. Acta Paediatr Scand 64:497-504, 1975.

4. Beall AC, Johnson PC, Driscoll T, Alexander JK, Dennis EW, McNamara DG, Cooley DA, DeBakey ME: Effect of total cardiopulmonary 
bypass on myocardial and blood digoxin concentrations in man. Am J Cardiol 11:194-200, 1963.

5. Berman W, Ravenscroft PJ, Sheiner LB, Heymann MA, Melmon KL, Rudolph AM: Differential effects of digoxin at comparable concentrations in tissues of fetal and adult sheep. Circ Res 411:635-642, 1977.

6. Berman WJ, Musselman J: Relationship of age to the metabolism and protein binding digoxin in sheep. J Pharmacol Exp Ther 208:263-266, 1979.

7. Berman WJ, Musselman J, Shortencarrier R: Localization of digoxin in sheep myocardium by immunofluorescent microscopy. Biol Neonate 40:295-299, 1981.

8. Biddle TL, Weintraub M, Lasanga L: Relationship of serum and myocardial digoxin concentration to electrocardiographic estimation of digoxin intoxification. J Clin Pharmacol 18: 10-15, 1978.

9. Coltart DJ, Gullner HG, Billingham M, Goldman RH, Stinson EB, Harrison DC: Physiological distribution of digoxin in human heart. $\mathrm{Br}$ Med J 4:733-736, 1974

10. Doherty JE, Perkins WH, Mitchell GK: Tritiated digoxin studies in human subjects. Arch Intern Med 108:531-539, 1961.

11. Doherty JE, Perkins WH, Flanigan WJ: The distribution and concentration of tritiated digoxin in human tissues. Ann Intern Med 66: 116-124, 1967.

12. Eichhorst $\mathrm{O}$, Hinderling PH: Specific assay for radiolabeled digoxin and its known apolar metabolites in biological fluids I. J Chromatogr 224:67-93, 1981 .

13. Eriksson B-M, Tekenbergs L: Determination of tritiated digoxin and metabolites in urine by liquid chromatography. J Chromatogr 223:401408, 1981

14. Ewy GA, Groves BM, Ball MF, Nimmo L, Jackson B, Marcus F: Digoxin metabolism in obesity. Circulation 44:810-814, 1971.

15. Gault MH, Sugden D, Maloney C, Ahmed M, Tweeddale M: Biotransformation and elimination of digoxin with normal and minimal renal function. Clin Pharmacol Ther 25:499-513, 1979.

16. Gibson TP, Nelson HA: Evidence of accumulation of digoxin metabolites in renal failure. Clin Res 27:665A, 1979. (Abst.)

17. Gibson TP, Nelson HA: The question of cumulation of digoxin metabolites in renal failure. Clin Pharmacol Ther 27:219-223, 1980.

18. Gorodischer R, Jusko WJ, Yaffe SJ: Tissue and erythrocyte distribution of digoxin in infants. Clin Pharmacol Ther 19:256-263, 1976.

19. Gullner HG, Stinson EB, Harrison DC, Kalman SM: Correlation of serum concentrations with heart concentrations of digoxin in human subjects. Circulation 50:653-655, 1974.

20. Hernandez A, Kouchoukos N, Burton RM, Goldring D: The effect of extracorporeal circulation upon the tissue concentration of digoxin${ }^{3} \mathrm{H}$. Pediatrics 31:952-957, 1963.

21. Hollynck TH, Soep HH, Thomas JA, Boelaert A, Daneels R, Dettli L: Should clearance be normalized to body surface or to lean body mass? Br J Clin Pharmacol 11:523-526, 1981.

22. Jusko WJ, Weintraub M: Myocardial distribution of digoxin and renal function. Clin PHARMaCol THER 16:449-454, 1974.

23. Karjalainem J, Ojala K, Reissell P: Tissue concentration of digoxin in autopsy material. Acta Pharmacol Toxicol 34:385-390, 1974.

24. Kim PW, Kirsula RW, Soyka LF, Hastierter AR: Postmortem tissue digoxin concentration in infants and children. Circulation 52:1128-1131, 1975.

25. Kramer WG, Bathala MS, Reuning RH: Specificity of the digoxin radioimmunoassay with respect to dihydrodigoxin. Res Comm Chem Pathol Pharmacol 14:83-88, 1976.

26. Krasula RW, Hastreiter AR, Levitsky S, Yanagi R, Soyka LF: Serum, atrial, and urinary digoxin levels during cardiopulmonary bypass in children. Circulation 49:1047-1052, 1974.

27. Lang D, Hofstetter R, von Bernuth G: Post mortem tissue and plasma concentrations of digoxin in newborns and infants. Eur $\mathrm{J}$ Pediatr 128: 151-161, 1978.

28. Loo JCK, McGilveray IJ, Jordan N: Quantitation of digoxigenin in serum following oral administration of digoxin in humans. Res Comm Chem Pathol Pharmacol 17:497-506, 1977.

29. Loo JCK, McGilveray IJ, Jordan N: The estimation of serum digoxin by combined HPLC separation and radioimmunological assay. $\mathrm{J} \mathrm{Liq}$ Chromatogr 4:879-886, 1981 .

30. Morais A, Zlotecki RA, Sakmar E, Stetson PL, Wagner JG: Specific and sensitive assays for digoxin in plasma, urine and heart tissue. Res Comm Chem Pathol Pharmacol 31:285-298, 1981.

31. Nelson HA, Lucas SV, Gibson TP: Isolation by high-performance liquid chromatography and quantitation by radioimmunoassay of therapeutic concentrations of digoxin and metabolites. J Chromatogr 163: 169-177, 1979.

32. Park MK, Ludden T, Arom KV, Rogers J, Oswalt JD: Myocardial vs serum digoxin concentrations in infants and adults. Am J Dis Child 136:418-420, 1982

33. Pinsky WW, Jacobsen JR, Gillette PC, Adams J, Monroe L, McNamara DG: Dosage of digoxin in premature infants. J Pediatr 94:639-642, 1979.

34. Sandoz GG, Bloom KR, Isukawa T, Patterson 
MWH, Rowe RD: Noninvasive assessment of left ventricular function related to serum digoxin levels in neonates. Pediatrics 65:541-546, 1980.

35. Stoll RG, Christensen MS, Sakmar E, Wagner JG: The specificity of the digoxin radioimmunoassay procedure. Res Comm Chem Pathol Pharmacol 4:503-510, 1972.

36. Wagner JG, Hallmark MR, Sakmar E, Ayres JW: Sensitive radioimmunoassay for digoxin in plasma and urine. Steroids 29:787-807, 1977.
37. Wagner JG, Popat KD, Das SK, Sakmar E, Movahhed $\mathrm{H}$ : Evidence of nonlinearity in digoxin pharmacokinetics. J Pharmacokinet Biopharm 9:147-166, 1981.

38. Weintraub $M$ and Lasagna $L$ : Serum and tissue concentrations of digoxin: A clinical and pathologic analysis. Clin Pharmacol Ther 14: 149, 1973. (Abst.) 